\title{
New Technologies for Surgery of the Congenital Cardiac Defect
}

\author{
David Kalfa, M.D., Ph.D.* and Emile Bacha, M.D. \\ Pediatric Cardiac Surgery, Columbia University, Morgan Stanley Children's Hospital of New York- \\ Presbyterian, New York, USA
}

\begin{abstract}
The surgical repair of complex congenital heart defects frequently requires additional tissue in various forms, such as patches, conduits, and valves. These devices often require replacement over a patient's lifetime because of degeneration, calcification, or lack of growth. The main new technologies in congenital cardiac surgery aim at, on the one hand, avoiding such reoperations and, on the other hand, improving long-term outcomes of devices used to repair or replace diseased structural malformations. These technologies are: 1) new patches: CorMatrix ${ }^{\circledR}$ patches made of decellularized porcine small intestinal submucosa extracellular matrix; 2) new devices: the Melody ${ }^{\circledR}$ valve (for percutaneous pulmonary valve implantation) and tissue-engineered valved conduits (either decellularized scaffolds or polymeric scaffolds); and 3) new emerging fields, such as antenatal corrective cardiac surgery or robotically assisted congenital cardiac surgical procedures. These new technologies for structural malformation surgery are still in their infancy but certainly present great promise for the future. But the translation of these emerging technologies to routine health care and public health policy will also largely depend on economic considerations, value judgments, and political factors.
\end{abstract}

KEY WORDS: Congenital heart defect, extracellular matrix patch, new technologies, percutaneous valve implantation, robotics, tissue engineering

\footnotetext{
Abbreviations: ECM, extracellular matrix; FDA, Food and Drug Administration; MSC, marrow stromal cells; P4HB, poly-4-hydroxybutyrate; PA, pulmonary artery; PCL, polycaprolactone; PCLA, poly-L-lactide; PGA, polyglycolic acid; PLA, poly(lactic acid); PLLA, poly-L-lactic acid; RV, right ventricle; RVOT, right ventricular outflow tract; SIS-ECM, small intestinal submucosa extracellular matrix.

Citation: Kalfa D, Bacha E. New Technologies for Surgery of the Congenital Cardiac Defect. Rambam Maimonides Med J 2013;4 (3):e0019. doi:10.5041/RMMJ .10119

Copyright: (C) 2013 Kalfa and Bacha. This is an open-access article. All its content, except where otherwise noted, is distributed under the terms of the Creative Commons Attribution License (http:// creativecommons.org/licenses/by/ 3.0), which permits unrestricted use, distribution, and reproduction in any medium, provided the original work is properly cited.
}

Conflict of interest: No potential conflict of interest relevant to this article was reported.

* To whom correspondence should be addressed. E-mail: davidkalfa@gmail.com 


\section{INTRODUCTION}

Congenital cardiac surgery frequently requires additional tissue such as patches, conduits, and valves. These prostheses are characterized by a risk of degeneration, calcification, and a lack of growth, and usually need a replacement over a patient's lifetime. The main new technologies in congenital cardiac surgery aim at improving long-term outcomes of these devices and avoiding reoperations.

\section{NEW PATCHES: CORMATRIX ${ }^{\circledR}$ EXTRACELLULAR MATRIX PATCHES}

Despite improvements in congenital heart surgery procedural mortality, there remain a substantial number of patients who need multiple reinterventions, ${ }^{1}$ because of the lack of growth potential and remodeling of currently used patches (autologous pericardium (with or without glutaraldehyde), preserved xenopericardium, and various prosthetic materials). As a matter of fact, the ideal patch still does not exist. Such an ideal material would not interfere with the patient's growth, would be pliable, soft, resistant to tearing, calcification, and shrinkage, and would possibly not induce remodeling of scar tissue.

Recently, the CorMatrix ${ }^{\circledR}$ (CorMatrix Alpharetta, GA) patch made of decellularized porcine small intestinal submucosa extracellular matrix (SISECM) has been introduced into cardiac surgery. The extracellular matrix (ECM) is the acellular component that surrounds cells in native tissues and is mainly composed of elastin, collagen (structural proteins), glycans (glycosaminoglycans, proteoglycans), and adhesion glycoproteins. These new patches have demonstrated patch remodeling and integration in animal models of cardiac surgery. ${ }^{2,3}$ Wainwright et al. ${ }^{4}$ showed that right ventricular outflow tract (RVOT) reconstruction with SIS-ECM patches in a rat model resulted in new cardiac tissue formation in the patched areas and the absence of ventricular dilatation, when compared with Dacron reconstructions of the RVOT.

These promisingresults in experimental studies have then been confirmed in human studies that specifically evaluated the outcomes of SIS-ECM in congenital heart surgery for cardiac and vascular reconstructions..$^{5-7}$ Scholl et al. ${ }^{5}$ demonstrated in one case of an explanted patch used for augmentation of the tricuspid valve that SIS-ECM was replaced by organized collagen and populated with endothelial-like cells four months after theimplant. Quarti et al.6 showed early encouraging results of these CorMatrix ${ }^{\circledR}$ patches used for vascular repair (pulmonary artery, ascending aorta, aorticarch, and right ventricular outflow tract), but also for valve reconstruction (aortic, tricuspid, mitral, and pulmonary valves) and pericardial closure. Witt et al. ${ }^{7}$ demonstrated that SIS-ECM is suitable for the closure of septal defects. But the use of SIS-ECM for the reconstructions of outflow tracts and great vessels in this study carried a small risk of stenosis, especially in patches that form the majority of the vessel circumference. Moreover these studies had rather a short follow-up. Another potential drawback of CorMatrix ${ }^{\circledR}$ ECM patches is the significant variability of theSIS-ECM biomechanical properties between different lots. Contrary to the Surgisis ${ }^{\mathrm{TM}}$ trial assessing the clinical use of SIS-ECM for carotid artery repair following endarteriectomy-a study that displayed an increased risk of aneurysm formation-the CorMatrix ${ }^{\circledR}$ lot did not display such a pejorative evolution even when implanted in highpressure systems. Nevertheless, thelimited numbers of patients in studies dealing with the implantation of CorMatrix ${ }^{\circledR}$ in high-pressure systems prevent their authors from speculating regarding the longterm effectiveness of the CorMatrix ${ }^{\circledR}$ in specific high-pressure locations. Long-term outcomes of these ECM patches depend not only on patch biomechanical properties, patch location, and hemodynamic environment, but also on the patient's immune response. Badylak et al. ${ }^{8}$ showed that the non-cross-linked SIS-ECM incited an immunoregulatory and proangiogenicmacrophageresponse (leading to remodeling and repopulation of the patch) instead of an inflammatory, scar-forming response (potentially leading to stenosis).

Porcine SIS-ECM is currently approved by the Food and Drug Administration (FDA) for use in humans. Nevertheless, large studies of the grouth potential of the porcine SIS-ECM compared to other biomaterials used in cardiac surgery have not been conducted yet.

To summarize, the CorMatrix ${ }^{\circledR}$ ECM displays a lot of potential advantages over other materials currently used in pediatric cardiac surgery, as follows:

- Easily handled and implantable

- Abundant

- Durable (still controversial)

- Minimal scar formation 
- Remodeling of the material (no calcification)

- Growth potential (still controversial)

This new biomaterial seems to provide an interim bioscaffold that enables the patient's own cells to repopulate and repair damaged tissues, which is of particular interest in patients with congenital heart diseases, forvalve repair, and vascular reconstruction. But the long-term performance of theSIS-ECM in congenital cardiac applications still needs to beassessed through longitudinal studies of greater magnitude.

\section{NEW DEVICES}

\section{Percutaneous Pulmonary Valve Implantation: The Melody ${ }^{\circledR}$ Valve}

The right ventricle (RV) to main pulmonary artery (PA) conduits that are used to reconstruct the right ventricular outflow tract in congenital heart diseases are prone to develop valvular incompetence and/or obstruction with time. These pejorative evolutions are associated with exercise intolerance, arrhythmias, and an increased risk of sudden death ${ }^{9}$ and require multiple open-heart surgeries to replace the pulmonary valve.

Percutaneous pulmonary valveimplantation was introduced as a new treatment option in patients with dysfunctional conduits. ${ }^{10,11}$ This technological breakthrough aims at prolonging the lifespan of RV to PA conduits and thus postponing open-heart surgery. The trans-catheter pulmonary valve(Melody ${ }^{\circledR}$; Medtronic, Minneapolis, MN) is composed of a bovine jugular venous valve and a balloonexpandable stent made of a platinum-iridium wire.

The current largely accepted indications for the use of a Melody ${ }^{\circledR}$ valve include ${ }^{12}$ :

- A significant RVOT obstruction, defined as RV pressures $>2 / 3$ of systolic blood pressure (SBP) with symptoms, or $>3 / 4$ of SBP without symptoms

- A severe pulmonary regurgitation and RV dysfunction or RV dilatation or impaired exercise capacity

- Along with morphological criteria allowing a safe implantation site: RVOT dimensions < $22 \times 22 \mathrm{~mm}$ and $>14 \times 14 \mathrm{~mm}$

Theimplantation procedure isstandardized and safe, with a procedural mortality $<0.2 \%$. The main complication to avoid during the implantation is coronary compression or occlusion, which can be evaluated by a pre-implantation balloon inflation in the RVOT. Other complications duringimplantation are the dislodgement of the device when implanted in distensible and dilated RVOTs and the risk of homograft rupture.

Valve implantation significantly reduces the gradient across theoutflow tract, RV pressures, and the pulmonary regurgitation, ${ }^{13}$ and significantly improves symptoms.

Lurz et al. ${ }^{13}$ demonstrated that during a median follow-up of 28 months freedom from reoperation was $93 \%( \pm 2), 86 \%( \pm 3), 84 \%( \pm 4)$, and $70 \%( \pm 13)$, at $10,30,50$, and 70 months, respectively.

Themain complications of the new generation of this innovative technology are late endocarditis and stent fractures in 20\%. ${ }^{14}$ These stent fractures are silent in the majority of cases and are treated in symptomatic patients with RVOT stenosis by a Melody ${ }^{\circledR}$ valve-in-valve implantation.

Pulmonary valve implantation is becoming the standard procedure in the treatment of dysfunctional conduits. It has been accepted by the regulatory agencies for distribution and use in Europe in 2006 and US Food and Drug Administration in 2010.

By prolonging the lifespan of RV- PA surgically placed conduits, this innovative technology has reduced the number of multiple open heart operations in children and young adults with congenital heart disease, and may improve their life expectancy and life quality.

As with all evolving new technologies, new generations of Melody valves were created in order to reduce current limitations and extend the spectrum of potential clinical indications. Improvements brought to the Melody ${ }^{\circledR}$ valve during the last few years of development or currently in progress include:

- Device design improvements

- Delivery system improvements

- Patient selection improvements using threedimensional echography and MRI

- Dilatation with high-pressure balloon after implantation (to reduce residual gradients)

- Stent-in-stent implantation

- Structural improvements to extend this technology to patients with native, dilated, and distensible RVOT 
These principles of percutaneousvalveimplantation are currently investigated in other off-label clinical settings. For instance, valves developed for trans-catheter replacement of the aortic valve were implanted in the pulmonary position for patients with larger annulus. ${ }^{15}$ A new device allowing the implantation of a pulmonary valve in a RVOT previously repaired with a transannularpatch is also currently investigated but not published yet.

Tissue-Engineered Valved Conduits: Decellularized Scaffolds, Polymer Scaffolds, and in Situ Regeneration

The ideal RV-PA conduit for reconstruction of the RVOT still does not exist.
Cryopreserved homografts need a revision surgery in 36\% and $90 \%$ of cases after 10 and 15 years, respectively. ${ }^{16-18}$ Hancock conduits need to be replaced after 10 years in $68 \%$ of cases, and $50 \%$ of Carpentier-Edwards Perimount ${ }^{\circledR}$ (Edwards Lifesciences, Irvine, CA, USA) valves (bioprosthetic stented valve made of bovine pericardium) implanted in children also have to be replaced after 5 years. ${ }^{19}$ Children younger than 2 years old operated with a Contegra ${ }^{\circledR}$ Medtronic conduit have to undergo a revision surgery in $67 \%$ of cases for failure. 20 The reoperations needed to replace a failing conduit carry a significant risk of mortality (1\%-3\%) and morbidity: hemorrhagic syndrome, cerebral vascular accident, coronary damage, cardiac rhythm alterations, or infection. These

Table 1. Current Surgical Valved Conduits to Replace the Right Ventricular Outflow Tract.

\begin{tabular}{|c|c|c|c|}
\hline Current Surgical Devices & Reoperation Rates & Limitations & Ref. \\
\hline Cryopreserved homografts & $\begin{array}{l}6 \%-58 \% \text { at } 5 \text { years, } 36 \%-90 \% \text { at } \\
15 \text { years, depending on the } \\
\text { diameter, age at surgery, and } \\
\text { heart defect }\end{array}$ & $\begin{array}{l}\text { - No growth potential } \\
\text { - Immunogenicity and } \\
\text { inflammatory response } \\
\text { - Calcification } \\
\text { - Structural degeneration } \\
\text { - Limited availability }\end{array}$ & 18,22 \\
\hline $\begin{array}{l}\text { Stented heterografts (e.g. } \\
\text { Hancock }{ }^{\circledR} \text { tube: porcine } \\
\text { aortic heart valve in a } \\
\text { tube made of Dacron }{ }^{\circledR} \text { ) }\end{array}$ & $\begin{array}{l}19 \% \text { at } 5 \text { years, } 68 \% \text { at } 10 \\
\text { years, } 95 \%-100 \% \text { at } 15 \text { years, } \\
\text { depending on the diameter, } \\
\text { age at surgery, and heart } \\
\text { defect }\end{array}$ & $\begin{array}{l}\text { - No growth potential } \\
\text { - Early calcification } \\
\text { - Structural degeneration } \\
\text { - Pannus formation } \\
\text { - Excessive stiffness with anatomic } \\
\text { compression/ distortion }\end{array}$ & 23 \\
\hline $\begin{array}{l}\text { Stentless heterografts } \\
\text { (e.g. Contegra }{ }^{\circledR} \text { tube: } \\
\text { bovine jugular vein) }\end{array}$ & $\begin{array}{l}22 \%-40 \% \text { at } 5 \text { years, depending } \\
\text { on the diameter, age at } \\
\text { surgery, and heart defect }\end{array}$ & $\begin{array}{l}\text { - No growth potential } \\
\text { - Immunogenicity and } \\
\text { inflammatory response } \\
\text { - Stenosis of the distal anastomosis } \\
\text { - Pseudoaneurysm of the proximal } \\
\text { anastomosis } \\
\text { - Severe conduit regurgitation }\end{array}$ & 24,25 \\
\hline $\begin{array}{l}\text { Stentless heterografts } \\
\text { (e.g. Shelhigh }{ }^{\circledR} \text { tube: } \\
\text { porcine pulmonary heart } \\
\text { valve in a tube made of } \\
\text { bovine pericardium) }\end{array}$ & $\begin{array}{l}48 \%-67 \% \text { at } 1 \text { year, depending } \\
\text { on the diameter, age at } \\
\text { surgery, and heart defect }\end{array}$ & $\begin{array}{l}\text { - Intimal peel formation at the } \\
\text { distal segment } \\
\text { - No growth potential } \\
\text { - Immunogenicity and } \\
\text { inflammatory response } \\
\text { - Pseudoaneurysm }\end{array}$ & 26 \\
\hline Mechanical valves & $\begin{array}{l}\text { Only in older children and } \\
\text { adults }\end{array}$ & $\begin{array}{l}\text { - No growth potential } \\
\text { - Anticoagulant therapy required } \\
\text { - Thromboembolic complications }\end{array}$ & 27 \\
\hline
\end{tabular}


complications translate into prolonged hospitalization and attendant costs. Surgical techniques have improved during the last three decades, but conduit failure and morbidity and mortality still occur (Table1). Autologous pericardial valved conduits for RVOT reconstruction showed superb properties, but data for long-term follow-up are lacking. ${ }^{21}$

As a consequence of the limited treatment options and the requirements for repeat surgery in children as they grow, newalternatives were investigated to reconstruct the RVOT. The advancedtherapy medicinal products (ATMPs) derived from the concept of regenerative medicine are presently seen as one of the main routes to reduce the abovementioned risks, with the exception of organ transplantation.

On the basis of these issues, the search for the ideal material to replace the RVOT started. The in vitro creation of autologous and living substitute materials by tissue engineering is based on the essential need for growth potential of materials to be used for surgical correction of congenital cardiac defects.

In the last 15 years, different tissue-engineered materials have been proposed to replace the RVOT. Scaffolds were either decellularized allo- or xenogenic biological valved conduits or bioabsorbable prosthetic materials (poly-4-hydroxybutyrate (P4HB), poly-L-lactide (PCLA), polyglycolic acid (PGA)) designed in unvalved patches, ${ }^{28-32}$ nonvalved tubes, ${ }^{33-35}$ or valved tubes. ${ }^{36-40}$

\section{Decellularized scaffolds}

Dohmen et al. published an account of the first clinical implantation of a tissue-engineered heart valve in $2000^{41}$ : an in vitro seeded decellularized pulmonary allograft was implanted during a Ross operation in an adult patient. The 10-year clinical results of these tissue-engineered heart valves of the same group were promising despite a limited number of patients. ${ }^{42}$ Da Costa et al. ${ }^{43}$ demonstrated an excellent hemodynamic behavior and a significant decrease in human leukocyte antigen (HLA) class I and II antigens in decellularized allografts compared with standard allografts. Nevertheless pejorative clinical outcomes of this technology were also reported: Simon et al. ${ }^{44}$ showed that the Synergraft technology failed in four grafts after 2 days and 1 year post-implantation and that no recellularization of the decellularized grafts was seen at up to 1year of follow-up. In 2010, Da Costa etal. 45 investigated the outcomes of decellularized aortic homograft implants as an aortic root replacement in 41 patients. No reoperations were performed due to aortic valvedysfunction with a maximal follow-up of 53 months.

\section{Polymer scaffolds and in situ regeneration concept}

The literature reports that polymer scaffolds were seeded (or not) with different types of autologous cells: endothelial cells, fibroblasts, myofibroblasts derived from peripheral vessels, ${ }^{28,32-35,36,37,39}$ smooth musclecells derived from aorta or cardiomyocytes. ${ }^{29}$ In vitro and in vivo studies (goats or adult syngenic rats) of these materials implanted in the RVOT demonstrated the biodegradation of the material, 28,29 the endothelialization of the surface of the material, $30,37,38$ the synthesis of an extracellular matrix, $28,33,35,37,38,46$ the absence of thrombus or stenosis, 36 and a low risk of calcification. In 2006, Hoerstrup et al. proved, in a pioneering work, the growth potential of abioabsorbablenon-valved tube seeded with endothelial cells and fibroblasts implanted on the pulmonary artery in a growing lamb model during 100 weeks. ${ }^{47}$ Concomitantly to this biological progress, other synthetic polymers (polyL-lactic acid (PLLA), ${ }^{48}$ poly(epsilon-caprolactone) (PCL) ${ }^{49}$ poly(styrene-block-isobutylene-blockstyrene) (SIBS), 50 poly (glycerol-sebacate) (PGS) ${ }^{51}$ ), and other biological materials (fibrin, ${ }^{52}$ collagen, ${ }^{53}$ 3D cardiac extracellular matrix, ${ }^{54}$ or hybrid materials55,56) were investigated to create tissueengineered scaffolds for heart valves. Some polymeric matrices were made "bioactive" through the implantation of growth factors on their surface (transforming growth factor beta, bone morphogenetic protein, and vascular endothelial growth factor). 57,58 Other research groups investigated strategies of "homing" and immobilization of circulating host-derived cells. 59

Materials designed for RVOT reconstruction by tissue engineering using stem cells were first evaluated in vitro. 60 They were bioabsorbable nonvalved patches or valved tubes (PGA $+/$ - P4HB or PGA+PLLA). The first stem cells used were human bone-marrow cells that displayed a myofibroblastic differentiation and synthetized an extracellular matrix. ${ }^{61}$ In 2007, autologous peripheral bloodderived endothelial progenitor cells and autologous bone-marrow-derived marrow stromal cells (MSC) were seeded on a bioabsorbablenon-valved patch on the pulmonary artery of seven goats with a follow-up 
of 6 weeks. ${ }^{62-66}$ This study showed the development of a living and organized tissue, integrated to the native pulmonary artery. The use of bioreactors for cell culture and maturation in dynamic conditions allowed for the maturation of the tissue-engineered device, the in vitro cell differentiation, and the formation of the extracellular matrix.67-72 A noninvasive percutaneous method of implantation of tissue-engineered heart valves was described by $\mathrm{Dr}$ Hoerstrup's group ${ }^{73}$ and by Emmert et al. ${ }^{74}$ From 2002, the cells used have been derived from human umbilical cord blood, Wharton's jelly, amniotic liquid, chorial villosities, or induced pluripotent cells seeded on non-valved patches or valved tubes. ${ }^{75-83}$ Even periodontal ligament cells cultured under steady flow environments demonstrated potential for use in heart valve tissue engineering.

Materials made of co-polymer of poly(lacticacid) (PLA) and polycaprolactone (PCL), seeded with human bone-marrow cells, were implanted by Shin'oka et al. in 42 patients with congenital heart diseases in J apan between 2001 and 2005.84,85 The incidence of early stenosis led this group to go back "from bed to bench" to further understand the mechanisms of this type of early failure. ${ }^{86}$

Prototypes of a bioabsorbable valve and valved tube created using PLLA reinforced with nonabsorbable polyester (PET) were assessed as tissueengineered devices to reconstruct the RVOT by the group of Menasché and Kalfa et al. (Figure 1).

Table 2 summarizes the different types of synthetic polymers used in the research field of the right ventricular outflow tract.

The concept of decellularization of tissue engineered heart valves, initially made of biodegradable synthetic materials and homologous cells, was then introduced to offer an alternative starter matrix for guided tissue regeneration. ${ }^{107}$ This decellularization phase of tissue-engineered heart valves was demonstrated not to alter the collagen structure or tissue strength; it also favored valve performance when compared to their cell-populated counterparts and could providelargely availableoffthe-shelf homologous scaffolds suitable for reseeding with autologous cells.

Key requirements and properties of those substrates were then discussed in the light of current trends toward designing biologically inspired microenvironments for in situ tissue engineering purposes. ${ }^{108}$ The concept of in situ

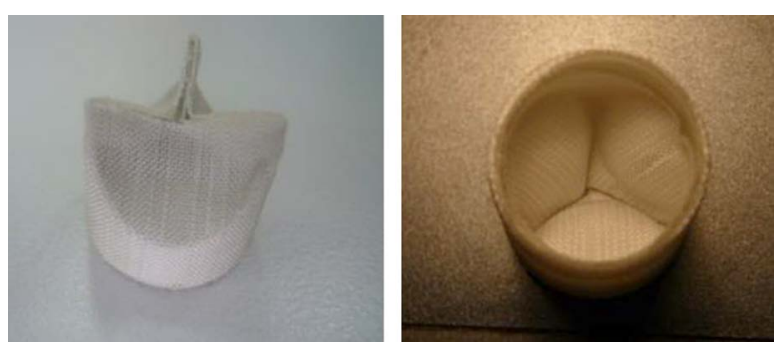

Figure 1. A Global View of a Bioabsorbable Valve Made of Poly-L-lactic acid (PLLA) and Polyester (PET).

Illustrations from D. Kalfa and P. Menasché's group.

tissue engineering, i.e. neotissue regeneration without the use of seeded cells, could solve the disadvantages of using any cell source and achieve a versatile and easier cell-free protocol. 109 The evaluation of in situ tissue engineeringvasculature(iTEV) by implantation of scaffolds made of polyglycolide knitted fibers and an L-lactide and $\varepsilon$-caprolactone co-polymer sponge in the inferior vena cava of a canine model supported this concept by demonstrating a native tissue-like histological regeneration, with acceptable biomechanical characteristics. ${ }^{110}$

More recently, hundreds of polymers were comprehensively assessed for tissue engineering of cardiac valves, using polymer microarray technology. ${ }^{111}$ Biomechanical tests with real-time displacement and strain mapping were also recently reported to quantify biomechanical and biochemical properties of semilunar heart valve tissues, and potentially facilitate the development of tissueengineered heart valves. 112 The role of substrate stiffness in modulating the gene expression and phenotype of neonatal cardiomyocytes in vitro ${ }^{113}$ or seeded human bone-marrow stem cells, 114 on the one hand, and in modulating the activation of valvular interstitial cells, 115 on the other hand, demonstrated the importance of the mechanical properties of materials used for valve repair or for engineering valve tissue. ${ }^{116}$

Electrospinning appears in the literature as a promising technology to produce scaffolds for cardiovascular tissue engineering. Amoroso et al. evaluated the effect of processing variables and secondary fiber populations on the microstructure and the tensile and bending mechanics of electrospun biodegradable polyurethane scaffolds for heart valve tissue engineering. ${ }^{117}$ Computational tools were developed in order to describe and predict the mechanical behavior of electrospun valve-shaped 
Table 2. Different Types of Synthetic Polymers Used in the Research Field of the Right Ventricular Outflow Tract.

n. a. =not applicable

\begin{tabular}{|c|c|c|c|}
\hline Polymer & Cell Type & Animal Model & Ref. \\
\hline Poly(ethylene glycol) (PEG) & $\begin{array}{l}\text { Human MSC, valvular interstitial } \\
\text { cells (VIC) }\end{array}$ & n.a. & $87-91$ \\
\hline $\begin{array}{l}\text { Poly(glycolic acid) } \\
\text { (PGA)/ Poly(lactic acid) (PLA) }\end{array}$ & $\begin{array}{l}\text { - Fibroblasts, epithelial cells } \\
\text { (EC) and ovine VIC } \\
\text { - Human fibroblasts, bovine } \\
\text { aortic EC }\end{array}$ & lambs (2 weeks) & 92,93 \\
\hline \multirow[t]{2}{*}{$\begin{array}{l}\text { PGA/ Poly-4-hydroxybutyrate } \\
\text { (P4HB) }\end{array}$} & $\begin{array}{l}\text { - Myofibroblasts, ovine EC } \\
\text { - Stem cells, endothelial } \\
\text { progenitor cells, and ovine } \\
\text { valvular endothelial cells (VEC) }\end{array}$ & lambs (20-100 weeks) & \multirow[t]{2}{*}{$94-98$} \\
\hline & $\begin{array}{l}\text { - Human amniotic fluid-derived } \\
\text { stem cells }\end{array}$ & sheep (8 weeks) & \\
\hline Polycaprolactone (PCL) & Human myofibroblasts & n.a. & 99 \\
\hline $\begin{array}{l}\text { Poly(glycerol sebacate) } \\
\text { (PGS)/ PCL }\end{array}$ & $\begin{array}{l}\text { Human umbilical vein-derived } \\
\text { endothelial cells (HUVEC) }\end{array}$ & n.a. & 100 \\
\hline Poly(ester urea urethane) (PEUU) & $\begin{array}{l}\text { Smooth muscle cells (SMC) from } \\
\text { rats }\end{array}$ & n.a. & 101-104 \\
\hline Polydioxaneone (PDO) & Ovine MSC & lambs (1, 4, 8 months) & 105 \\
\hline $\begin{array}{l}\text { Polycarbonate PCU- Polyhedral } \\
\text { oligomeric silsesquioxanes (POSS) }\end{array}$ & n. a. & n.a. & 106 \\
\hline
\end{tabular}

scaffolds characterized by different microstructures and showed that a pronounced degree of anisotropy was necessary to reproduce the deformation patterns observed in the native heart valve. 118

In the emerging field of tissue engineering and regenerative medicine, different design strategies were evaluated to promote the development and evaluation of improved tissue engineering scaffolds. These include mimicking the extracellular matrix, predicting the structural architecture, ensuring adequateinitial mechanical integrity, modifyingthe surface chemistry 109,110,119 and topography ${ }^{120}$ to provide cell signaling, and anticipatingthe material selection so as to predict the required rate of bioresorption. ${ }^{121}$ The biofunctionalization of polymeric scaffolds or decellularized native homografts with motifs (such as RGD, SDF-1a, fibronectin, collagen, CD33) led to encouragingresults and could be an alternative way to the complex techniques of cell culture and cell seeding.109,110,122 Prokoph et al. demonstrated that sustained delivery of SDF-1a from proangiogenic hydrogels could effectively attract early endothelial progenitor cells (ePCs), offering a powerful means to trigger endogenous mechanisms of cardiac regeneration. ${ }^{122}$

\section{NEW FIELDS}

\section{Antenatal Corrective Cardiac Surgery}

Embryology and fetal physiopathology of congenital cardiac defects support the idea that the natural progression of some malformations could be curtailed, or arrested altogether, by an intrauterine intervention on the developing heart. Moreover, prenatal diagnosis is performed more and more widely and precisely. This led to the idea of corrective interventions in the fetus, now regarded as a new frontier in pediatric cardiac surgery. Three types of cardiac surgical procedures have been performed so far in the fetus: aortic valvuloplasty in 
hypoplastic left heart syndrome, ${ }^{123,124}$ atrial septostomy to prepare surgery of the same syndromeafter birth, 125 and pulmonary valvuloplasty for pulmonary atresia and hypoplastic right ventricle. Central to progress in this area is the development of instrumentation specifically designed for minimally invasive cardiac surgery in the fetus, involving experts in microengineering and microrobotics. An "ideal" catheter for minimally invasive, fetal cardiac surgery should therefore be appropriately miniaturized and implemented with sensors and driving systems. Some parts of the ideal "fetal catheter" are already available as a prototype. ${ }^{126}$ Such fetal "mechanical" surgical procedures could then be combined with fetal "biological" procedures such as implantation of an appropriatelineage of stem cells or any suitable grouth-promoting factor inside the fetal ventricle wall. Collaborations with surgeons, cardiologists, imagers, and engineers will be mandatory to develop such new integrated technologies.

\section{Robotics}

Robotically assisted surgical procedures have been introduced into the field of cardiac surgery since the late 1990s. The da Vinci ${ }^{\circledR}$ Surgical System (Intuitive Surgical, Inc., Sunnyvale, CA) is the only US FDAapproved system for intracardiac procedures. Robotics was first applied in pediatric cardiac surgery for extracardiac procedures such as patent ductus arteriosus ligation and vascular ring divisions. ${ }^{127-129}$ Robotically assisted repairs of atrial septal defect were then performed in children. 131,132 There has also been an on-going interest in developingimage-guided techniques to perform the same types of intracardiac repairs currently done as open procedures, but without use of cardiopulmonary bypass. To meet this objective, technical advances need to be achieved in two domains: the creation of instruments and devices providing tactile feedback and steerability, on the one hand,132 and high-resolution 3D real-timeimaging, on the other hand. ${ }^{133,134}$ Thus, new catheter-like robotic delivery platforms have been described that facilitate safe navigation and enable complex repairs, such as tissue approximation and fixation, and tissue removal, inside the beating heart. 135

These new systems combined with enhanced imaging techniques may enable the advancement of the field of beating-heart intracardiac reconstructive interventions currently not feasible with available surgical and catheter-based robotic systems. ${ }^{136}$

\section{CONCLUSION}

Thesenew technologies for structural malformation surgery are still in their infancy but certainly present great promise for the future. Further development of these technologies will depend on the collaboration among diverse medical specialties and thecontribution from engineers with special skills. But the translation of these emerging technologies to routine health careand public health policy will also largely depend on economic considerations, value judgments, and political factors.

\section{REFERENCES}

1. Warnes CA, Williams RG, Bashore TM, et al. ACC/AHA 2008 Guidelines for the Management of Adults with Congenital Heart Disease: a report of the American College of Cardiology/American Heart Association Task Force on Practice Guidelines (writing committee to develop guidelines on the management of adults with congenital heart disease). Circulation 2008;118:e714- 833. Full Text

2. Robotin-J ohnson MC, Swanson PE, Johnson DC, Schuessler RB, Cox J L. An experimental model of small intestinal submucosa as a growing vascular graft. J Thorac Cardiovasc Surg 1998;116:805- 11. Full Text

3. Ruiz CE, Iemura M, Medie S, et al. Transcatheter placement of a low-profile biodegradable pulmonary valve made of small intestinal submucosa: a longterm study in a swine model. J Thorac Cardiovasc Surg 2005; 130:477-84. Full Text

4. Wainwright J M, Hashizume R, Fujimoto KL, et al. Right ventricular outflow tract repair with a cardiac biologic scaffold. Cells Tissues Organs 2012;195:15970. Full Text

5. Scholl FB, Boucek MM, Chan K-C, Valdes-Cruz L, Perryman R. Preliminary experience with cardiac reconstruction using decellularized porcineextracellular matrix scaffold: human applications in congenital heart disease. World J Pediatr Congenital Heart Surg 2010;1:132-6. Full Text

6. Quarti A, Nardone S, Colaneri M, Santoro G, Pozzi M. Preliminary experience in the use of an extracellular matrix to repair congenital heart diseases. Interact Cardiovasc Thorac Surg 2011;13:569- 72. Full Text

7. Witt RG, Raff G, Van Gundy J, Rodgers-Ohlau M, Si MS. Short-term experience of porcinesmall intestinal submucosa patches in paediatric cardiovascular surgery. EurJ Cardiothorac Surg 2013;44:72-6. Full Text 
8. Badylak S, Kokini K, Tullius B, Simmons-Byrd A, Morff R. Morphologic study of small intestinal submucosa as a body wall repair device. J Surg Res 2002;103:190-202. Full Text

9. Frigiola A, Redington AN, Cullen S, Vogel M. Pulmonary regurgitation is an important determinant of right ventricular contractiledysfunction in patients with surgically repaired tetralogy of Fallot. Circulation 2004;110(11 Suppl 1):II153- 7.

10. Bonhoeffer P, Boudjemline Y, Saliba Z, et al. Percutaneous replacement of pulmonary valve in a right-ventricle to pulmonary-artery prosthetic conduit with valvedysfunction. Lancet 2000;356:14035. Full Text

11. Bonhoeffer P, Boudjemline Y, Qureshi SA, et al. Percutaneous insertion of the pulmonary valve.J Am Coll Cardiol 2002;39:1664- 9. Full Text

12. Lurz P, Gaudin R, Taylor AM, Bonhoeffer P. Percutaneous pulmonary valve implantation. Semin Thorac Cardiovasc Surg Pediatr Card Surg Annu 2009:112- 17. Full Text

13. Lurz P, Coats L, KhambadkoneS, etal. Percutaneous pulmonary valve implantation: impact of evolving technology and learning curve on clinical outcome. Circulation 2008;117:1964- 72. Full Text

14. Nordmeyer J, Khambadkone S, Coats L, et al. Risk stratification, systematic classification, and anticipatory management strategies for stent fracture after percutaneous pulmonary valve implantation. Circulation 2007;115:1392- 7. Full Text

15. Chowdhury SM, Hijazi ZM, Rhodes J, et al. Early echocardiographic changes after percutaneous implantation of the Edwards SAPIEN transcatheter heart valve in the pulmonary position. Echocardiography 2013 Feb 22. [Epub ahead of print] Full Text

16. Kalfa D, Loundou A, Nouaille de Gorce Y, et al. Pulmonary position cryopreserved homograft in nonRoss patients: how to improve the results? Eur J Cardiothorac Surg 2012;42:981- 7. Full Text

17. Kalfa D, Feier H, Loundou A, et al. Cryopreserved homograft in the Ross procedure: outcomes and prognostic factors.J Heart Valve Dis 2011;20:571-81

18. Kalfa D, Macé L, Metras D, Kreitmann B. How to choose the best available homograft to reconstruct the right ventricular outflow tract. J Thorac Cardiovasc Surg 2011;142:950- 3. Full Text

19. KwakJ G, LeeJ R, Kim WH, Kim YJ . Mid-termresults of the Hancock II valve and Carpentier-Edward Perimount valve in the pulmonary portion in congenital heart disease. Heart Lung Circ 2010;19:2436. Full Text
20. Brown JW, Ruzmetov M, Rodefeld MD, Vijay P, Turrentine MW. Right ventricular outflow tract reconstruction with an allograft conduit in non-ross patients: risk factors for allograft dysfunction and failure. Ann Thorac Surg 2005;80:655- 63. Full Text

21. Yan SM, Mishaly D, Shinfeld A, Raanani E. Right ventricular outflow tract reconstruction: valved conduit of choiceand clinical outcomes. J Cardiovasc Med (Hagerstown) 2008;9:327-37. Full Text

22. Zachariah JP, Pigula FA, Mayer JE J r, McElhinney DB. Right ventricle to pulmonary artery conduit augmentation compared with replacement in young children. Ann Thorac Surg 2009;88:574-80. Full Text

23. Belli E, Salihoğlu E, Leobon B, et al. The performance of Hancock porcine-valved Dacron conduit for right ventricular outflow tract reconstruction. Ann Thorac Surg 2010;89:152- 7. Full Text

24. Urso S, Rega F, Meuris B, etal. The Contegra conduit in the right ventricular outflow tract is an independent risk factor for graft replacement. Eur J Cardiothorac Surg 2011;40:603- 9.

25. Holmes AA, Co S, Human DG, LeblancJ G, Campbell AI. The Contegra conduit: late outcomes in right ventricular outflow tract reconstruction. Ann Pediatr Cardiol 2012;5:27-33. Full Text

26. Kim WH, Min SK, Choi $\mathrm{CH}$, et al. Follow-up of Shelhigh porcine pulmonic valve conduits. Ann Thorac Surg 2007;84:2047- 50. Full Text

27. Horere J, Vogt M, Stierle U, et al. A comparative study of mechanical and homograft prostheses in the pulmonary position. Ann Thorac Surg 2009;88: 1534-9. Full Text

28. Stock UA, Sakamoto T, Hatsuoka S, et al. Patch augmentation of the pulmonary artery with bioabsorbable polymers and autologous cell seeding. J Thorac Cardiovasc Surg 2000;120:1158-67.Full Text

29. Sakai $T$, Li RK, Weisel RD, et al. The fate of a tissueengineered cardiac graft in the right ventricular outflow tract of the rat. J Thorac Cardiovasc Surg 2001; 121:932- 42. Full Text

30. Ozawa T, Mickle DA, Weisel RD, Koyama N, Ozawa S, Li RK. Optimal biomaterial for creation of autologous cardiac grafts. Circulation 2002;106(12 Suppl 1): I176- 82.

31. Ozawa T, Mickle DA, Weisel RD, et al. Histologic changes of nonbiodegradable and biodegradablebiomaterials used to repair right ventricular heart defects in rats. J Thorac Cardiovasc Surg 2002;124: 1157-64. Full Text

32. Ozawa T, Mickle DA, Weisel RD, et al. Tissueengineered grafts matured in the right ventricular outflow tract. Cell Transplant 2004;1:169- 77. 
33. Shinoka T, Shum-Tim D, Ma PX, et al. Creation of viable pulmonary artery autografts through tissue engineering. J Thorac CardiovascSurg 1998;115:53645. Full Text

34. Hoerstrup SP, Kadner A, Breymann C, et al. Living, autologous pulmonary artery conduits tissue engineered from human umbilical cord cells. Ann Thorac Surg 2002; 74:46- 52. Full Text

35. Leyh RG, Wilhelmi M, RebeP, Ciboutari S, Haverich A, Mertsching $\mathrm{H}$. Tissue engineering of viable pulmonary arteries for surgical correction of congenital heart defects. Ann ThoracSurg2006;81:1466- 70. Full Text

36. Stock UA, Nagashima M, Khalil PN, et al. Tissue engineered valved conduits in the pulmonary circulation. J Thorac Cardiovasc Surg 2000;119(4Pt 1):73240. Full Text

37. Steinhoff G, Stock U, Karim N, et al. Tissue engineering of pulmonary heart valves on allogenic acellular matrix conduits: in vivo restoration of valve tissue. Circulation 200;102(19 Suppl 3):III50- 5.

38. Leyh RG, Wilhelmi $M$, Rebe $P$, et al. In vivo repopulation of xenogeneic and allogeneic acellular valve matrix conduits in the pulmonary circulation. Ann Thorac Surg 2003;75:1457-63. Full Text

39. Leyh R, Wilhelmi M, Haverich A, Mertsching H. [A xenogeneic acellularized matrix for heart valvetissue engineering: in vivo study in a sheep model]. Z Kardiol 2003;92:938-46. [Article in German] Full Text

40. Kim WG, Huh JH. Time related histopathologic changes of acellularized xenogenic pulmonaryvalved conduits. ASAIOJ 2004;50:601- 5. Full Text

41. Dohmen PM, LembckeA, Hotz H, Kivelitz D, Konertz WF. Ross operation with a tissue-engineered heart valve. Ann Thorac Surg 2002;74:1438-42. Full Text

42. Dohmen PM, Lembcke A, Holinski S, Pruss A, KonertzW. Ten years of clinical results with a tissueengineered pulmonary valve. Ann Thorac Surg 2011; 92:1308-14. Full Text

43. da Costa FD, Dohmen PM, Duarte D, et al. Immunological and echocardiographic evaluation of decellularized versus cryopreserved allografts during the Ross operation. Eur J Cardiothorac Surg 2005; 27:572-8. Full Text

44. Simon P, Kasimir MT, Seebacher G, et al. Early failure of the tissue engineered porcine heart valve SYNERGRAFT in pediatric patients. Eur J Cardiothorac Surg 2003;23:1002- 6. Full Text

45. da Costa FD, Costa AC, Prestes R, et al. The early and midterm function of decellularized aortic valve allografts. Ann Thorac Surg 2010;90:1854-60. Full Text
46. Sales VL, Engelmayr GC Jr, Johnson JA Jr, et al. Protein precoating of elastomeric tissue-engineering scaffolds increased cellularity, enhanced extracellular matrix protein production, and differentially regulated the phenotypes of circulating endothelial progenitor cells. Circulation 2007;116(11 Suppl):I55- 6 .

47. Hoerstrup SP, Cummings Mrcs I, Lachat M, et al. Functional growth in tissue-engineered living, vascular grafts: follow-up at 100 weeks in a large animal model. Circulation 2006;114(1Suppl):I159- 66.

48. Eckert CE, Mikulis BT, Gottlieb D, et al. Threedimensional quantitative micromorphology of pre and post-implanted engineered heart valve tissues. Ann Biomed Eng 2011;39:205-22. Full Text

49. Del Gaudio C, Grigioni M, Bianco A, De Angelis G. Electrospun bioresorbable heart valve scaffold for tissue engineering. Int J ArtifOrgans 2008;31:68- 75.

50. Wang Q, McGoron AJ , Bianco R, Kato Y, Pinchuk L, Schoephoerster RT. In-vivo assessment of a novel polymer (SIBS) trileaflet heart valve. J Heart Valve Dis 2010; 19:499- 505.

51. Masoumi N, J ean A, Zugates JT, Johnson KL, Engelmayr GC Jr. Laser microfabricated poly(glycerol sebacate) scaffolds for heart valvetissue engineering. J Biomed Mater ResA 2013;101:104- 14. Full Text

52. Flanagan TC, Sachweh J S, Frese J, et al. In vivo remodeling and structural characterization of fibrinbased tissue-engineered heart valves in the adult sheep model. Tissue Eng Part A 2009;15:2965- 76. Full Text

53. Tedder ME, Simionescu A, Chen J, Liao J, Simionescu DT. Assembly and testing of stem cellseeded layered collagen constructs for heart valve tissue engineering. Tissue EngPartA 2011;17:25- 36. Full Text

54. Mainwright J M, Hashizume R, Fujimoto KL, et al. Right ventricular outflow tract repair with a cardiac biologic scaffold. Cells Tissues Organs 2012;195:15970. Full Text

55. Hong H, Dong N, Shi J , et al. Fabrication of a novel hybrid heart valveleaflet for tissue engineering: an in vitro study. Artif Organs 2009;33:554- 8. Full Text

56. Duan B, Wu L, Yuan X, et al. Hybrid nanofibrous membranes of PLGA/chitosan fabricated via an electrospinning array. J Biomed Mater Res A 2007;83:868- 78. Full Text

57. Chiu YN, Norris RA, Mahler G, Recknagel A, Butcher JT. Transforming growth factor $\beta$, bone morphogenetic protein, and vascular endothelial growth factor mediate phenotype maturation and tissue remodeling by embryonic valve progenitor cells: 
relevance for heart valve tissue engineering. Tissue Eng Part A 2010;16:3375-83. Full Text

58. Chiu LL, Radisic M, Vunjak-Novakovic G. Bioactive scaffolds for engineering vascularized cardiactissues. Macromol Biosci 2010;10:1286-301. Full Text

59. Schleicher M, Wendel HP, Fritze O, StockUA. Invivo tissue engineering of heart valves: evolution of a novel concept. Regen Med 2009;4:613- 19. Full Text

60. Siepe M, Akhyari P, Lichtenberg A, Schlensak C, Beyersdorf F. Stem cells used for cardiovascular tissue engineering. Eur J Cardiothorac Surg 2008; 34:242- 7. Full Text

61. Kadner A, Hoerstrup SP, Zund G, et al. A new source for cardiovascular tissue engineering: human bone marrowstromal cells. EurJ Cardiothorac Surg2002; 21:1055- 60. Full Text

62. Mendelson, K, Aikawa E, Mettler BA, et al. Healing and remodeling of bioengineered pulmonary artery patches implanted in sheep. Cardiovasc Pathol 2007; 16:277-82. Full Text

63. Sales VL, Mettler BA, Lopez-Ilasaca M, J ohnson JA $\mathrm{Jr}$, Mayer JE Jr. Endothelial progenitor and mesenchymal stem cell-derived cells persistin tissueengineered patch in vivo: application of green and red fluorescent protein-expressing retroviral vector. Tissue Eng 2007;13:525- 35. Full Text

64. Mettler BA, Sales VL, Stucken CL, et al. Stem cellderived, tissue-engineered pulmonary artery augmentation patches in vivo. Ann Thorac Surg 2008; 86:132- 40. Full Text

65. Sales VL, Mettler BA, Engelmayr GC Jr, et al. Endothelial progenitor cells as a sole source for ex vivo seeding of tissue-engineered heart valves. Tissue Eng Part A 2010;16:257-67. Full Text

66. Gottlieb D, Kunal T, Emani S, et al. In vivo monitoring of function of autologous engineered pulmonary valve. J Thorac Cardiovasc Surg 2010;139:723-31. Full Text

67. Van Vlimmeren MA, Driessen-Mol A, Oomens CW, Baaijens FP. Thepotential of prolonged tissueculture to reduce stress generation and retraction in engineered heart valve tissues. Tissue Eng Part C Methods 2013;19:205- 15. Full Text

68. Rubbens MP, Driessen-Mol A, Boerboom RA, et al. Quantification of the temporal evolution of collagen orientation in mechanically conditioned engineered cardiovascular tissues. Ann Biomed Eng 2009; 37:1263- 72. Full Text

69. Ramaswamy S, Gottlieb D, Engelmayr GC Jr, et al. Therole of organ level conditioning on thepromotion of engineered heart valvetissue developmentin-vitro using mesenchymal stem cells. Biomaterials 2010; 31:1114- 25. Full Text

70. Martinez C, Rath S, Van Gulden S, et al. Periodontal ligament cells cultured under steady-flow environments demonstrate potential for use in heart valve tissue engineering. Tissue Eng Part A 2013;19:45866. Full Text

71. Ziegelmueller JA, Zaenkert EK, Schams R, et al. Optical monitoring during bioreactor conditioning of tissue-engineered heart valves. ASAIO J 2010;56: 228-31. Full Text

72. Vismara R, Soncini M, Talò G, et al. A bioreactor with compliance monitoring for heart valve grafts. Ann Biomed Eng 2010;38:100- 8. Full Text

73. Schmidt D, Dijkman PE, Driessen-Mol A, et al. Minimally-invasive implantation of living tissue engineered heart valves: a comprehensive approach from autologous vascular cells to stem cells. J Am Coll Cardiol 2010;56:510-20. Full Text

74. Emmert MY, Weber B, Behr L, et al. Transapical aortic implantation of autologous marrow stromal cell-based tissue-engineered heart valves: first experiences in the systemic circulation. J ACC Cardiovasc Interv 2011;4:822-3. Full Text

75. Kadner A, Hoerstrup SP, Tracy J, et al. Human umbilical cord cells: a new cell source for cardiovascular tissue engineering. Ann Thorac Surg 2002;74:S1422-8. Full Text

76. Breymann C, Schmidt D, Hoerstrup SP. Umbilical cord cells as a source of cardiovascular tissue engineering. Stem Cell Rev 2006;2:87-92. Full Text

77. Schmidt D, Achermann J, Odermatt B, et al. Prenatally fabricated autologous human living heart valves based on amniotic fluid derived progenitor cells as single cell source. Circulation 2007;116(11 Suppl): I64- 70.

78. Schmidt D, Mol A, Breymann C, et al. Living autologous heart valves engineered from human prenatally harvested progenitors. Circulation 2006; 114(1 Suppl):I125- 31.

79. Sodian R, Schaefermeier P, Abegg-Zips S, etal. Useof human umbilical cord blood-derived progenitor cells for tissue-engineered heart valves. Ann Thorac Surg 2010;89:819-28. Full Text

80. Sha J M, Yan ZY, Cheng GC, et al. In-vitro seeding of human umbilical cord vein endothelial cells on hydroxyapatite for mechanical heart valve applications. J Heart Valve Dis 2010;19:506- 12.

81. Kadner A, Zund G, Maurus C, etal. Human umbilical cord cells for cardiovascular tissue engineering: a comparative study. EurJ Cardiothorac Surg2004;25: 635- 41. Full Text 
82. Schmidt D, Breymann C, Weber A, et al. Umbilical cord blood derived endothelial progenitor cells for tissue engineering of vascular grafts. Ann Thorac Surg 2004; 78:2094- 8. Full Text

83. Schmidt D, Mol A, Neuenschwander S, et al. Living patches engineered from human umbilical cord derived fibroblasts and endothelial progenitor cells. EurJ Cardiothorac Surg 2005;27:795- 800. Full Text

84. Shin'oka T, Matsumura G, Hibino N, et al. Midterm clinical result of tissue-engineered vascular autografts seeded with autologous bone marrow cells. J Thorac Cardiovasc Surg 2005; 129:1330-8. Full Text

85. Weber B, Schoenauer R, Papadopulos F, et al. Engineering of living autologous human umbilical cord cell-based septal occluder membranes using composite PGA-P4HB matrices. Biomaterials 2011; 32:9630- 4 . Full Text

86. Udelsman BV, Maxfield MW, Breuer CK. Tissue engineering of blood vessels in cardiovascular disease: moving towards clinical translation. Heart 2013;99:454-60. Full Text

87. Benton JA, Fairbanks BD, Anseth KS. Characterization of valvular interstitial cell function in three dimensional matrix metalloproteinase degradable PEG hydrogels. Biomaterials 2009;30:6593-603. Full Text

88. BentonJA, Kern HB, Anseth KS. Substrateproperties influence calcification in valvular interstitial cell culture. J Heart Valve Dis 2008;17:689-99.

89. Kloxin AM, Benton JA, Anseth KS. In situ elasticity modulation with dynamic substrates to direct cell phenotype. Biomaterials 2010;31:1-8. Full Text

90. Kloxin AM, Tibbitt MW, Anseth KS. Synthesis of photodegradable hydrogels as dynamically tunable cell culture platforms. Nat Protoc 2010;5:1867-87. Full Text

91. Kloxin AM, Kasko AM, Salinas CN, Anseth KS. Photodegradable hydrogels for dynamic tuning of physical and chemical properties. Science 2009; 324:59-63. Full Text

92. Shinoka T, Breuer CK, Tanel RE, et al. Tissue engineering heart valves: valve leaflet replacement study in a lamb model. Ann Thorac Surg 1995; 60:S513-16. Full Text

93. Zund G, Breuer CK, Shinoka $T$, et al. The in vitro construction of a tissue engineered bioprosthetic heart valve. EurJ Cardiothorac Surg 1997;11:493- 7. Full Text

94. Hoerstrup SP, Sodian R, Daebritz S, et al. Functional living trileaflet heart valves grown in vitro. Circulation 2000;102:III44-9. Full Text
95. Sodian R, SperlingJ S, Martin DP, et al. Fabrication of a trileaflet heart valve scaffold from a polyhydroxyalkanoate biopolyester for use in tissue engineering. Tissue Eng 2000;6:183-8. Full Text

96. Schmidt D, Mol A, Odermatt B, et al. Engineering of biologically active livingheart valveleaflets usinghuman umbilical cord-derived progenitor cells. Tissue Eng 2006; 12:3223-32. Full Text

97. Dvorin EL, Wylie-Sears J, Kaushal S, Martin DP, Bischoff J. Quantitative evaluation of endothelial progenitors and cardiacvalveendothelial cells: proliferation and differentiation on poly-glycolicacid/ poly4-hydroxybutyrate scaffold in response to vascular endothelial growth factor and transforming growth factor beta1. Tissue Eng 2003;9:487-93. Full Text

98. Hoerstrup SP, Kadner A, Melnitchouk S, et al. Tissue engineering of functional trileaflet heart valves from human marrow stromal cells. Circulation 2002; 106:I143-50.

99. van Lieshout MI, Vaz CM, Rutten MC, Peters GW, Baaijens FP. Electrospinning versus knitting: two scaffolds for tissue engineering of the aortic valve. J Biomater Sci Polym Ed 2006;17:77-89. Full Text

100. Sant S, Hwang CM, Lee SH, Khademhosseini A. Hybrid PGS-PCL microfibrous scaffolds with improved mechanical and biological properties. J Tissue Eng Regen Med 2011;5:283-91. Full Text

101. Courtney T, Sacks MS, Stankus J, Guan J, Wagner WR. Design and analysis of tissue engineering scaffolds that mimic soft tissue mechanical anisotropy. Biomaterials 2006;27:3631-8.

102. Stankus JJ, Guan J, Fujimoto K, Wagner WR. Microintegrating smooth muscle cells into a biodegradable, elastomeric fiber matrix. Biomaterials 2006;27:735- 44. Full Text

103. StellaJ A, D'AmoreA, Wagner WR, Sacks MS. On the biomechanical function of scaffolds for engineering load-bearing soft tissues. Acta Biomater 2010;6:2365- 81. Full Text

104. Stella JA, Liao J, Hong Y, David Merryman W, Wagner WR, Sacks MS. Tissue-to-cellularlevel deformation coupling in cell micro-integrated elastomeric scaffolds. Biomaterials 2008;29:3228-36. Full Text

105. Kalfa D, Bel A, Chen-Tournoux A, et al. A polydioxanone electrospun valved patch to replace the right ventricular outflow tract in a growing lamb model. Biomaterials 2010;31:4056- 63. Full Text

106. Kidane AG, Burriesci G, Edirisinghe M, Ghanbari H, Bonhoeffer P, Seifalian AM. A novel nanocomposite polymer for development of synthetic heart valve leaflets. Acta Biomater 2009;5:2409- 17. Full Text 
107. Dijkman PE, Driessen-Mol A, Frese L, Hoerstrup SP, Baaijens FP. Decellularized homologous tissueengineered heart valves as off-the-shelf alternatives to xeno- and homografts. Biomaterials 2012;33: 4545- 54. Full Text

108. Bouten CV, Dankers PY, Driessen-Mol A, Pedron S, Brizard AM, Baaijens FP. Substrates for cardiovascular tissue engineering. Adv DrugDeliv Rev2011; 63:221- 41. Full Text

109. Patterson JT, Gilliland T, Maxfield MW, et al. Tissueengineered vascular grafts for use in the treatment of congenital heart disease: from the bench to the clinic and back again. Regen Med 2012;7:409- 19. Full Text

110. Matsumura G, Nitta N, Matsuda S, et al. Long-term results of cell-free biodegradable scaffolds for in situ tissue-engineering vasculature: in a canine inferior vena cava model. PLoS One 2012; 7:e35760. Full Text

111. Peragallo S, Tura O, Wu M, et al. Novel biopolymers to enhance endothelialisation of intra-vascular devices. Adv HealthcMater 2012;1:646-56. Full Text

112. Huang HY, Balhouse BN, Huang S. Application of simplebiomechanical and biochemical tests to heart valve leaflets: implications for heart valve characterization and tissue engineering. Proc Inst Mech EngH 2012;226:868- 76. Full Text

113. Forte G, Gliari S, Ebara M, et al. Substrate stiffness modulates gene expression and phenotype in neonatal cardiomyocytes in vitro. Tissue Eng Part A 2012;18:1837-48. Full Text

114. Emani S, MayerJ EJr, Emani SM. Generegulation of extracellular matrix remodeling in human bone marrow stem cell-seeded tissue-engineered grafts. Tissue Eng Part A 2011;17:2379- 88. Full Text

115. Quinlan AM, Billiar KL. Investigating the role of substrate stiffness in the persistence of valvularinterstitial cell activation. J Biomed Mater Res A 2012;100:2474- 82.

116. van Vlimmeren MA, Driessen-Mol A, Oomens CW, Baaijens FP. Passive and active contributions to generated force and retraction in heart valve tissue engineering. Biomech Model Mechanobiol 2012;11: 1015- 27. Full Text

117. Amoroso NJ , D'Amore A, Hong Y, Rivera CP, Sacks MS, Wagner WR. Microstructural manipulation of electrospun scaffolds for specific bendingstiffness for heart valve tissue engineering. Acta Biomater 2012; 8:4268- 77. Full Text

118. Argento G, Simonet M, Oomens CW, Baaijens FP. Multi-scale mechanical characterization of scaffolds for heart valve tissue engineering. J Biomech 2012; 45:2893-8. Full Text
119. Baumann L, Prokoph S, Gabriel C, Freudenberg U, Werner C, Beck-Sickinger AG. A novel, biased-like SDF-1 derivative acts synergistically with starPEGbased heparin hydrogels and improves eEPC migration in vitro. J Control Release 2012;162:68- 75. Full $\underline{\text { Text }}$

120. Nikkah M, Edalat F, Manoucheri S, Khademhosseini A. Engineering microscale topographies to control the cell-substrate interface. Biomaterials 2012;33: 5230-46. Full Text

121. Chung S, King MW. Design concepts and strategies for tissue engineering scaffolds. Biotechnol Appl Biochem 2011;58:423- 38. Full Text

122. Prokoph S, Chavakis E, Levental KR, et al. Sustained delivery of SDF-1 $\alpha$ from heparin-based hydrogels to attract circulating pro-angiogenic cells. Biomaterials 2012;33:4792-800. Full Text

123. Bacha EA. Impact of fetal cardiac intervention on congenital heart surgery. Semin Thorac Cardiovasc SurgPediatr Card SurgAnnu 2011; 14:35- 7. Full Text

124. Kohl T, Sharland G, Allan LD, et al. World experience of percutaneous ultrasound-guided balloon valvuloplasty in human fetuses with severe aortic valve obstruction. AmJ Cardiol 2000;85:1230-3. Full Text

125. Marshall AC, van der Velde ME, Tworetzky W, et al. Creation of an atrial septal defect in utero for fetuses with hypoplastic left heart syndrome and intact or highly restrictive atrial septum. Circulation 2004;110: 253-8. Full Text

126. Coceani F, Menciassi A, Murzi B. Antenatal corrective cardiac surgery: an emerging area for technological innovation. Minim Invasive Ther Allied Technol 2010;19:170-6. Full Text

127. Le Bret E, Papadatos S, Folliguet T, et al. Interruption of patent ductus arteriosus in children: robotically assisted versus videothoracoscopic surgery. J Thorac Cardiovasc Surg 2002;123:973-6. Full Text

128. Mihaljevic T, Cannon JW, del Nido PJ . Robotically assisted division of a vascular ring in children. J Thorac Cardiovasc Surg 2003; 125:1163-4. Full Text

129. Suematsu Y, Mora BN, Mihaljevic T, del Nido PJ . Totally endoscopic robotic-assisted repair of patent ductus arteriosus and vascular ring in children. Ann Thorac Surg 2005;80:2309- 13. Full Text

130. Bacha EA, Bolotin G, Consilio K, Raman J, Ruschhaupt DG. Robotically assisted repair of sinus venosus defect. J Thorac Cardiovasc Surg 2005; 129:442- 3. Full Text

131. Argenziano M, Oz MC, Kohmoto T, et al. Totally endoscopic atrial septal defect repair with robotic assistance. Circulation 2003;108(Suppl):II191-4. Full $\underline{\text { Text }}$ 
132. Butler E, Folk C, Cohen A, et al. Metal MEMS tools for beating-heart tissue approximation. IEEE Int Conf Robot Autom 2011;2011:411- 16.

133. Vasilyev NV, Melnychenko I, Kitahori K, et al. Beating-heart patch closure of muscular ventricular septal defects under real-time three-dimensional echocardiographic guidance: a preclinical study. J Thorac Cardiovasc Surg 2008; 135:603-9. Full Text

134. Deng J , Rodeck CH. Current applications of fetal cardiac imaging technology. Curr Opin Obstet Gynecol 2006;18:177-84. Full Text
135. Vasilyev NV, Dupont PE, del Nido PJ . Robotics and imaging in congenital heart surgery. Future Cardiol 2012;8:285-96. Full Text

136. Cannon J W, Howe RD, Dupont PE, Triedman J K, Marx GR, del Nido PJ . Application of robotics in congenital cardiac surgery. Semin Thorac Cardiovasc Surg Pediatr Card Surg Annu 2003;6:72-83. Full $\underline{\text { Text }}$ 